The Journal of Development and Administrative Studies, Vol. 22, No. 1-2, pp. 27-36, 2014

(c) CEDA/TU, 2000, US Library of Congress, Catlog Card No.: 79-915209, ISSN: 2091-0339

\title{
Impact of Corporate Social Responsibility on Corporate Governance and Reputation in Nepalese Commercial Banks
}

- Mahananda Chalise

\begin{abstract}
Corporate social responsibility (CSR) has been the subject of considerable investigation and debate for many years among both scholars and practitioners. Corporate social responsibility (CSR), corporate governance (CG) and corporate reputation (CR) influence the development of firms mostly. In this paper, a model of dynamic relations among CSR, corporate governance and corporate reputation was constructed in the theoretical framework of stakeholder. The model reflects that corporate reputation is formed in the dynamic relations between firms and corporate stakeholders, and corporate reputation is the synthesized result of corporate governance and CSR. For the purpose of testing the fitness of the model in Nepal, an empirical study is conducted on the relationship between corporate governance, CSR and corporate reputation. The result shows that good CSR has positive effect on banks reputation. It also indicates that $C G$ and $C R$ don't have significant relationship, but coefficient of the intervariable $\left(C G^{*} C S R\right)$ is significant and positive, which reflects that good corporate governance alone can't bring good reputation, but it can't when it comes with good social responsibility.
\end{abstract}

Keywords: CSR, corporate governance, banks reputation, stakeholder

JEL classification numbers: G38, G30 and M14

\section{Introduction}

At the very beginning of this century, a series of corporate frauds happened in developed and underdeveloped countries which made the corporate governance become the focus of these countries. The fraud brought positive effect to the corporate performance and stakeholders' interest, and even made some firms go bankrupt (Friedman, 1970). Under such background, many experts thought about

\footnotetext{
Dr. Chalise is an Associate Professor in Central Department of Management, Kirtipur, Tribhuvan University, Email:mahanchalise@gmail.com.
} 
the traditional questions about firms again: What is the goal of a firm? Who is the firm responsible for? Which social responsibility should a firm take? After rethinking of those questions, many experts focus on the effect and relationship between corporate social responsibility and corporate governance.

Corporate governance and corporate social responsibility are often mentioned with firm frauds. Especially now, with the modern media, any frauds can have negative and even fatal effect on fame and performance of the firm. Certainly, if a firm does well in the corporate governance and social responsibility, it will get good reputation (Lev, Baruch, 2006). Good reputation can bring value added ( Asyraf Wajdi Dusuki, Humayon Dar, 2006); eventually the firm can benefit its performance and have sustainable development.

With competition among commercial banks turning strong in Nepal, corporate reputation is to be a main channel for banks to get competition advantage. At the same time, more and more attentions are paid to corporate governance and corporate social responsibility in Nepalese commercial banks, but it is not clear on the relationship of Corporate governance, corporate social responsibility and banks reputation. At first this article analyses how the corporate governance and corporate social responsibility affect the commercial banks reputation, secondly it describes the relationship with the Nepalese data, and thirdly it gives results some implications for the Nepalese commercial banks.

Corporate governance and corporate social responsibility are important factors for the long-term development of a firm. Sometime their contents are same. Even some academicians think that the only difference between them is the way to speak. Actually, although corporate governance and corporate social responsibility are strongly related, they have different concepts. According to the research on the theory of corporate governance and corporate social responsibility, it is found that both of them are often put in the same framework of Stakeholder theory (Chalise, et.al, 2013).

\section{Theoretical Approach of the Study}

\subsection{Stakeholder theory}

Generally the proponents of stakeholder theory posit that paying attention to the interests, needs and rights of multiple stakeholders of a business is a useful way of inculcating socially responsible behavior among corporations (Goodpaster, 2001). The focus of stakeholder theory is articulated in two core questions (Freeman, 1994). First, it asks, what is the purpose of the firm? This encourages managers to articulate the shared sense of the value they create, and what brings its core stakeholders together. This propels the firm forward and allows it to generate 
outstanding performance, determined both in terms of its purpose and marketplace financial metrics. Second, stakeholder theory asks, what responsibility does management have to stakeholders? This pushes managers to articulate how they want to do business - specifically, what kinds of relationships they want and need to create with their stakeholders to deliver on their purpose.

As we examine, what kind of groups should be included in the stakeholders besides shareholders. We see various explanations being highlighted by stakeholder theorists. Freeman (1984) distinguishes between primary stakeholders (owners, management, local community, customers, employees and suppliers), whose continuing participation is necessary for the survival of the corporation, and secondary stakeholders (the government and communities that provide infrastructure and markets, trade unions and environmentalists), who are not essential to the survival of the corporation although their actions can significantly damage (or benefit) the corporation. Brenner and Cochran's (1991) listing of stakeholders includes stockholders, wholesalers, sales force, competition, customers, suppliers, managers, employees, and government. Donaldson and Preston (1995) diagram investors, political groups, customers, employees, trade associations, suppliers, and governments as stakeholders, which are widely accepted.

According to the Stakeholder theory, although shareholders are the most important stakeholders and the profit is the core objective of a firm, when a firm try to meet them it must think the interest of other stakeholders. It is required that corporate managers understand their stakeholder environments and manage more effectively within the nexus of relationships that exists for their companies. The whole point of stakeholder theory, in fact, lies in what happens when corporations and stakeholders act out their relationships (freeman, 2004).

\subsection{CSR and corporate governance}

There are a variety of definitions of CSR and no overall agreement. Generally speaking, CSR is concerned with treating the stakeholders of the firm ethically or in a responsible manner. 'Ethically or responsible' means treating stakeholders in a manner deemed acceptable in civilized societies. Social includes economic responsibility. Stakeholders exist both within a firm and outside. The natural environment is a stakeholder. By preserving the profitability of the corporation, the wider aim of social responsibility is to create higher and higher standards of living for the people both within and outside the corporation (Hopkins, 2004). However, from the perspective of stakeholder, corporate social responsibility posits on the issues what should the firm do for the stakeholders, in other words, CSR means "what to do" for the stakeholders. 
Chalise: Impact of Corporate Social Responsibility on Corporate Governance and Reputation ....

As to corporate governance, the OECD provides the most authoritative functional definition of corporate governance: "Corporate governance is the system by which business corporations are directed and controlled. The corporate governance structure specifies the distribution of rights and responsibilities among different participants in the corporation, such as the board, managers, shareholders and other stakeholders, and spells out the rules and procedures for making decisions on corporate affairs. By doing this, it also provides the structure through which the company objectives are set, and the means of attaining those objectives and monitoring performance." The significance of corporate governance for the stability and equity of society is captured in the broader definition of the concept offered by Sir Adrian Cadbury (2002): "Corporate governance is concerned with holding the balance between economic and social goals and between individual and communal goals. The governance framework is there to encourage the efficient use of resources and equally to require accountability for the stewardship of those resources. The aim is to align as nearly as possible the interests of individuals, corporations and society."

According to the above analysis, it is found that the main goal of corporate governance is to design and arrange suitable institution to built good relationship between firms and stakeholders. It concludes that there is difference between corporate governance and corporate social responsibility. Corporate social responsibility pays much attention to "what to do" for the stakeholders, corporate governance pay attention to "how to do". So firms must deal well with both of them to benefit stakeholders (see figure 1).

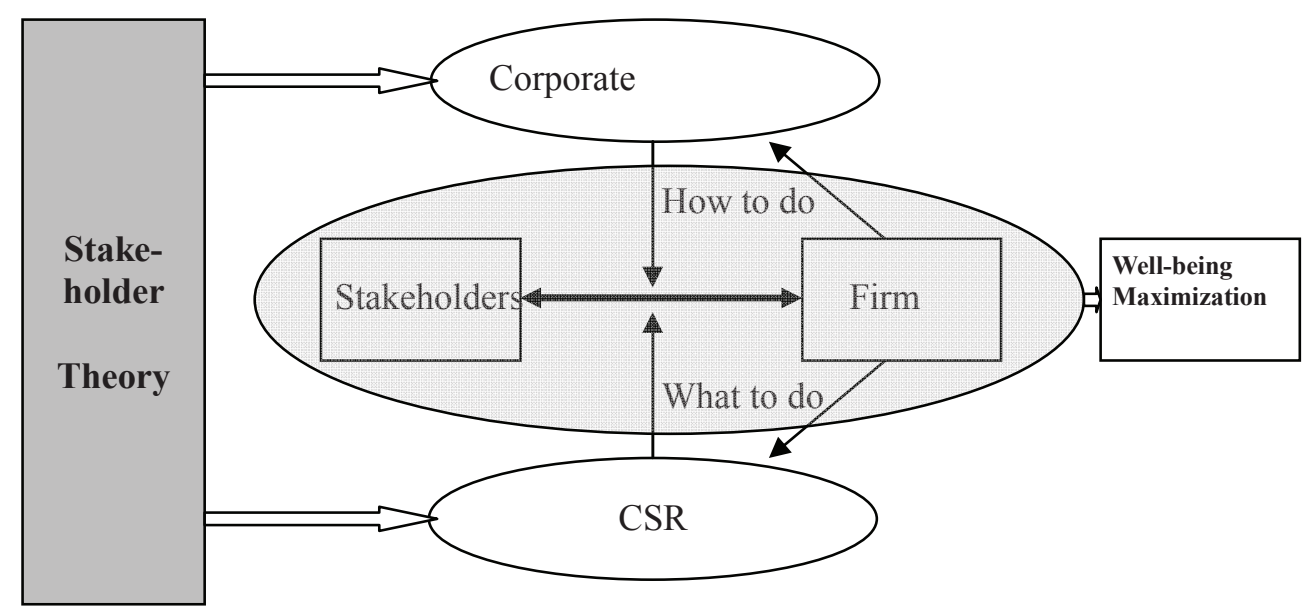

Figure 1: The relationship between corporate governance and CSR 


\section{Effects of Corporate Governance and CSR on Firm Reputation}

Corporate reputation is a major and growing concern globally, and it is increasingly being managed from a strategic perspective, because both managers and academicians think the good firm reputation will bring more interest to firms. Fombrun (1990) indicates that high reserves of reputational capital give organization distinct advantages: first, their products and stock offerings entice more customers and investors - and command higher prices. Second, their jobs lure more applicants and generate more loyalty and productivity from their employees. Third, their clout with suppliers is greater - and they pay lower prices for purchases and have more stable revenues. Finally, their risks of crisis are fewer - and when crises do occur, they survive with less financial loss (Fombrun, C. and Shanley, 1990). Meanwhile, Fombrun's (1996) definition of corporate reputation has been more widely used than most. Fombrun (1990) defines corporate reputation as "a perceptual representation of a company's past actions and future prospects that describes the firm's overall appeal to all of its key stakeholders when compared with other leading rivals".

\subsection{The source of firm reputation}

Firm reputation originates from recognition and comment of stakeholders, and stakeholders often judge a firm by its behavior on the product and capital market. These markets are the main place for firms to produce and manage, and information transfer between firms and stakeholders also happens in the markets. The performance of firms in the two markets and the relationship with firms formulate own opinions of stakeholders which would eventually turn to firm reputation.

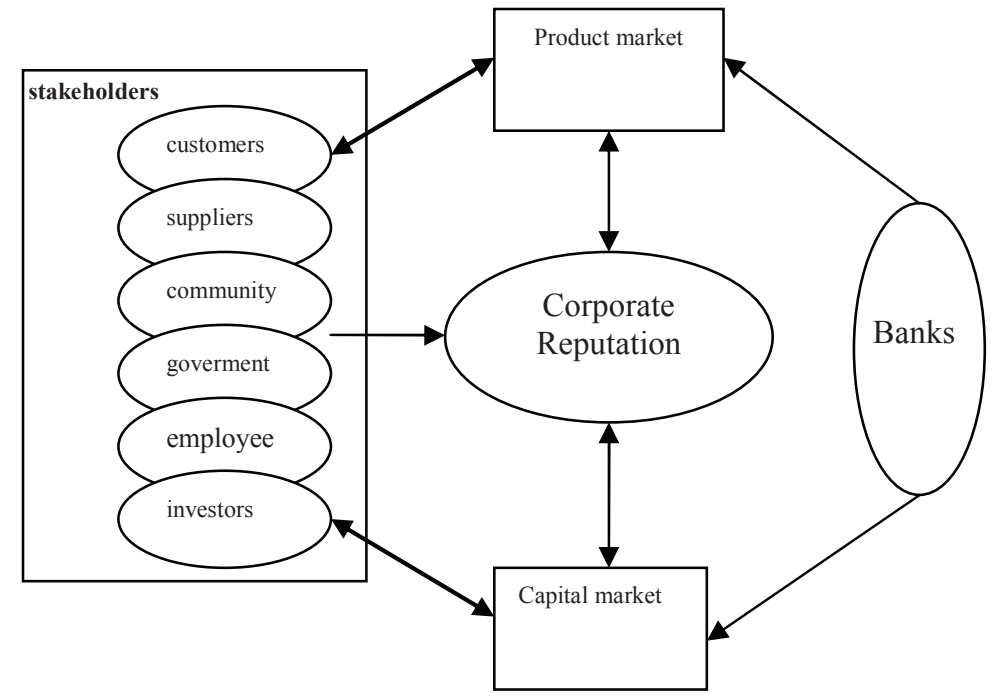

Figure 2: The two sources of firm reputation 
In the same way, there are effects of firm reputation to firm performance in the production and capital market. Greenley and Foxall (1997) use a broader approach recognizing firm performance in relation to various stakeholders. They find that companies that do not take account of the interests of their stakeholders, with low reputation, exhibit poor performance. Roger C, Vergin and M.W, Qoronfleh(1998) take a study on the 400 firms with good reputation. They find not only consumers pay more attention to the production of those firms, but also creditors favor those firms. By further study they conclude that firm reputation has positive effect on the firm's stock price.

In the capital market, investors prefer to buy the stock of firms with good reputation. And good corporate governance is a token of good reputation.

A survey from Mckinsey shows that investor will pay premium for the stock of firms with good corporate governance, which is regarded as having high corporate reputation by investors. Since corporate governance is involved in most of corporate stakeholders especially investors in capital market, so corporate reputation is directly influenced by corporate governance.

In product market, it is difficult to distinguish good product from bad one because of the increasing complexity of the product. Customers prefer to buy products from firms of good reputation, which comes from corporate social responsibility. In other words, CSR is the typical character of corporate reputation. In recent years, society's expectations for CSR have grown with the improvement of consciousness of CSR in many countries. Many companies have been working to improve their corporate reputation by expanding their CSR efforts, investing in staff, protecting environment, disclosing more information and integrating CSR into corporate strategy, which benefit corporate reputation. According to some survey, the banks which publish annual social responsibility reports easily get high evaluation from stakeholders.

\subsection{Dynamic model among CSR, corporate governance and corporate reputation}

From the above analysis of the effects of corporate governance and CSR on corporate reputation, a dynamic model which illustrates the relations among CSR, corporate governance and corporate reputation is constructed (figure 3).In this model, corporate reputation is shaped from the dynamic relations between stakeholders and firms in product/service market and capital market, which decides that corporate governance and corporate social responsibility are the main source to build corporate reputation. 


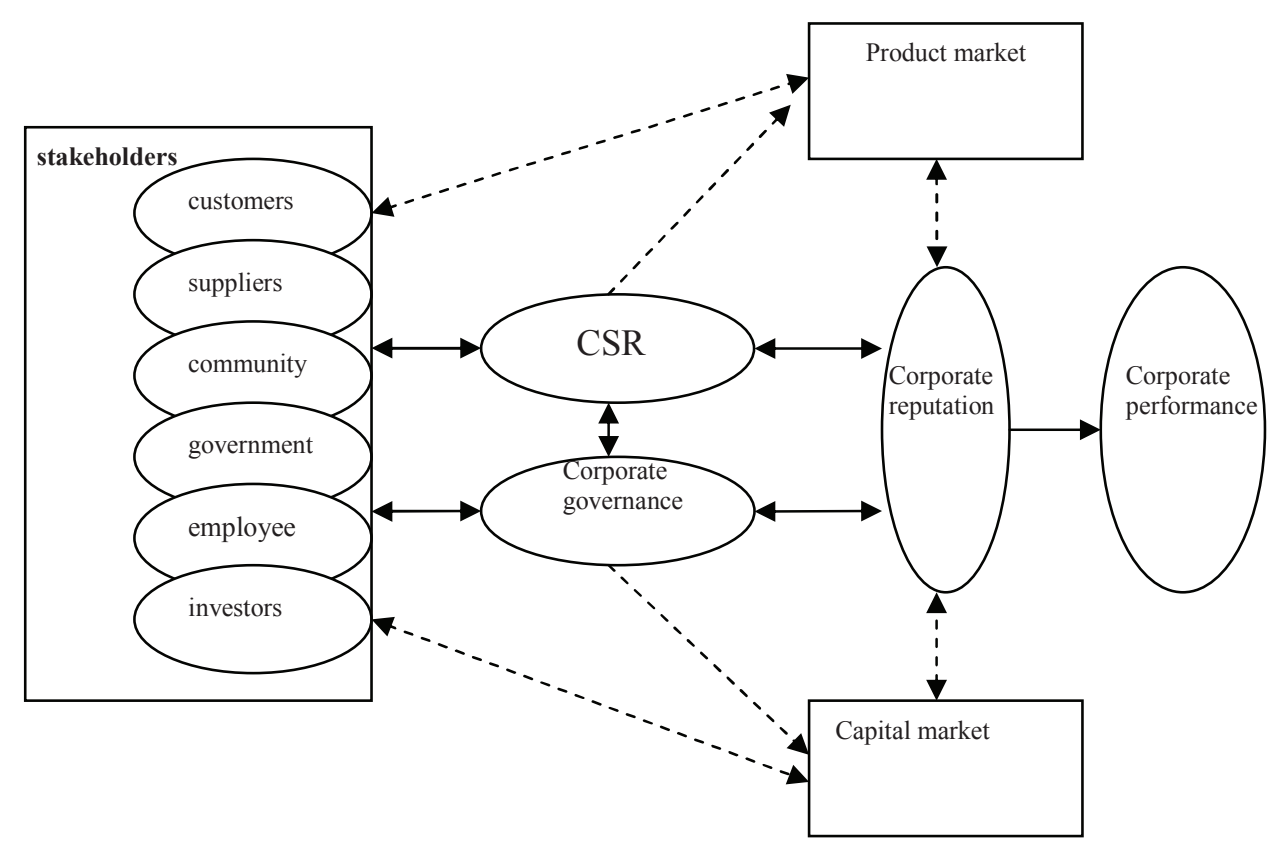

Figure 3: The conceptual dynamic model

\section{Empirical Study: An Approach to Commercial Banks}

Banking industry in Nepal developed very rapidly since 2003. In this process, more and more attention are paid in the banking industry reputation, corporate governance and corporate social responsibility and many commercial banks try their best to form good reputation to get competitive advantage. The study is based on empirical test of theory above on commercial banks reputation, corporate governance and corporate social responsibility based on the data of Nepalese commercial banks.

\subsection{The model and data}

According to the above theoretical analysis, it assures that the banks with good corporate governance and good corporate social responsibility have good reputation. Karen et al. (2003) find that commercial banks reputation is also affected by the banks scale/size, and the bigger bank scale/size will have good effect on banking industry reputation. The model is as follows:

$$
\mathrm{CR}=\mathrm{C}+\beta_{1} \mathrm{CG}+\beta_{2} \mathrm{CSR}+\beta_{3} \mathrm{CG}^{*} \mathrm{CSR}+\beta_{4} \ln (\mathrm{BS})
$$

Note: $\quad \mathrm{CR}$--corporate reputation; $\mathrm{CG}$-corporate governance;

CSR - corporate social responsibility; BS—Bank size 
It is hard to measure banks reputation, which is the dependent variable in the empirical model. The value of a key corporate brand and the primary intangible asset for many companies are often used to represent the firm reputation (Khermouch et al., 2001). In this paper, the data has been obtained of different commercial banks for banks reputation from famed banks in Nepal.

Corporate governance (CG) and corporate social responsibility (CSR) are two independent variables based on review of literature. According to former literature, the bank size (BS) as control variable has been used. As to the sample, first 25 commercial banks from different level banks in Nepal which was chosen by the Bankers Association of Nepal (BAN) and NRB data bank are selected. And then some commercial banks have been omitted in the absence of detailed data and information, and only 18 commercial banks, which have more than 5 years age of operation, are taken as sample banks, the crude data is gathered from the website and annual reports of those banks.

\subsection{Data analysis}

Table 1: The empirical result

\begin{tabular}{|l|l|l|l|l|}
\hline Variables & \multicolumn{4}{l|}{ Coeff. and T-stats } \\
\hline CG & 23.5 & 42.9 & 16.51 & \\
& $(0.65)$ & $(1.07)$ & $(0.53)$ & \\
\hline CSR & 4.65 & 0.99 & 4.22 & 3.34 \\
& $(2.38) * *$ & $(2.73) * *$ & $(2.48) * *$ & $(2.83) * * *$ \\
\hline CG* CSR & 0.90 & & 0.79 & 0.58 \\
& $(1.87) *$ & & $(1.90) *$ & $(1.95) *$ \\
\hline Constant & -112.27 & 163.48 & 80.30 & 13.28 \\
& $(0.075)$ & $(1.19)$ & $(0.06)$ & $(0.51)$ \\
\hline ln(FS) & 0.31 & 0.22 & & \\
& $(0.49)$ & $(0.04)$ & & \\
\hline R-squared & 0.25 & 0.17 & 0.23 & 0.19 \\
\hline Observations & 48 & 48 & 48 & 48 \\
\hline
\end{tabular}

Note: *significant at 10\%; **significant at 5\%; ***significant at $1 \%$

Table 1 reports coefficient estimates. The CSR clearly appears to increase the banks reputation, which indicates good CSR has positive effect on banks reputation. It also shows that $\mathrm{CG}$ and $\mathrm{CR}$ don't have significant relationship, but coefficient of the inter-variable $\left(\mathrm{CG}^{*} \mathrm{CSR}\right)$ is significant and positive, which reflects that good corporate governance alone can't bring good reputation, but it can when it comes with good social responsibility. So it is found that reputation of Nepalese commercial banks in Nepal mostly comes from good behavior in service 
and product market and good corporate governance can defend corporate reputation from becoming worse.

\section{Concluding Remarks}

In this paper, the research on the relations among corporate social responsibility, corporate governance and corporate reputation is in the theoretical framework of stakeholders, on the basis of which a model of dynamic relations among CSR, corporate governance and corporate reputation is constructed. The model reflects that corporate reputation is formed in the dynamic relations between commercial banks and corporate stakeholders, and corporate reputation is the synthesized result of corporate governance and CSR. For the purpose of testing the fitness of the model in Nepal, an empirical study is conducted on the relationship between corporate governance, CSR and corporate reputation by a sample of 18 Nepalese commercial banks. The result shows that good CSR has positive effect on bank reputation. It also indicates that CG and CR don't have significant relationship, but coefficient of the inter-variable (CG*CSR) is significant and positive, which reflects that good corporate governance alone can't bring good reputation, but it can when it comes with good social responsibility. The research implies that banks reputation mainly comes from its exhibitions in providing services in service market in Nepal, but banks reputation in capital market is ignored. Nepalese commercial banks should acknowledge that firm reputation comes not only from service and product market, but also from capital market. Furthermore, strengthening corporate governance is the most efficient way to improve Nepalese banks reputation in capital market.

In a customer driven economy, Nepalese commercial banks would have to reinvent themselves. CSR can help in the process by managerial risks, help to avoid scandals, and help companies to gain a unique selling position. It is found that government should accept moral responsibility for the well-being of their citizens and play a very proactive role to ensure that CSR is promoted. The role of government lays in providing clear guidance to the business world about CSR and corporate governance policies to be institutionalized in Nepalese commercial banks. It will take much hard work to develop a comprehensive CSR approach tailored to current and future needs and situation in Nepalese organizations. However, partnerships and good scope of joint activities including government, civil society, non-profit sector and private sector can significantly contribute to the success. 


\section{REFERENCES}

Andrews, K. (1980). The Concept of the Corporation. Homewood, IL: Irwin.

Asyraf, W.D and Humayon, D. (2006). Does corporate social responsibility pay off? An empirical examination of stakeholder perspectives. Working Paper, Department of Economics of Loughborough University

Caspar, R. and Steen, T. (2004). The impact of corporate reputation on performance: some Danish evidence, European Management Journal, 22(2), 201-210.

Chalise, M. and Bajracharya, P. (2013). Institutionalization of corporate social responsibility in Nepalese organizations. University Grants Commission, Nepal.

Donaldson, T. and Preston, L. (1995). The stakeholder theory of the modern corporation: Concepts, evidence and implications. Academy of Management Review, 20, 65-91.

Fombrun, C. and Shanley, M. (1990). What's in a name? Reputation building and corporate strategy. Academy of Management Journal, 233-258.

Fombrun, C. J. (1996). Realizing Value from the Corporate Image. Boston: Harvard Business School Press.

Freeman R. E., and Andrew, C. W. (2004). Bidhan parmar, stakeholder Theory and the corporate objective revisited. Organization Science, 15(3), 364-369

Freeman, R. E.(1994). The politics of stakeholder theory. Bus. Ethics Quart, 409421.

Friedman, M. (1970). The social responsibility of business is to increase its profits. The New York Times Magazine, 122-126.

Karen C. and Oliver, R. (2003). The reputation index: Measuring and managing corporate reputation, European Management Journal, 21(2), 201-212.

Khermouch, G., Holmes, S., and Ihlwan, M. (2001). The best global brands. The Business Week, $6^{\text {th }}$ August, 50-64.

Lev, B., Christine P., and Suresh, R. (2006). "Is doing good good for you? Yes, charitable contributions enhance revenue growth. Working paper, New York University Stern School of Business.

Roger C, Vergin and Qoronfleh, M. (1998). Corporate reputation and the stock market. Business Horizons, January-February, 19-26. 